\title{
СОМАТИЧНЕ ПРАВО ЛЮДИНИ НА МОДИФІКАЦІЮ СВОГО ТІЛА
}

\author{
ТУРЯНСЬКИЙ Юрій Іванович - доктор економічних наук, член НКР \\ Конституційного суду України \\ DOI:10.32782/LAW.2020.1.2 \\ УДК 340.12: 342.726
}

Модибікація тіла съогодні відбувається по всьому світу в різних бормах $i$ з багатьох причин. Історично в багатьох культурах здійснювалися обмежувальні та виснажливі модибікаиї жіночих тіл. Нині практика $\epsilon$ іншою, як то використання косметичноі хірургія, пірсинг тіла, татуювання та інші. Тендениія модибікацій тіла розиирюється новими та все більш химерними методами.

Науковці сучасний процес розширення способів модифікациї тіла, а основне їх активно зростаючу популярність називають процесом «демократизачія» модифікаиіі тіла. Також доводиться, що суспільний смак змінюється, тому татуювання та інші модибокачї̈ тіла сприймалися як законні форми вираження, з вираженою особистістю через татуювання.

Правове регулювання модифікаиї тіла не відмічається иіткістю. Европейсъкі країни зводять об'єм регулювання до встановлення віку за яким особа може здійснювати модифікаиійні дї та ліщензування фахівиів. Останній вид діяльності не врегульований національними нормами иивільного права.

Проаналізовано, щзо щодо віку позииій країн також розбіжні. Більшість держав дозволяють татуювання після повноліття, однак деякі держави передбачають право отримання дозволу у батьків у більш ранньому вічі Австралія, Австрія Хорватія, Словаччина, Україна (від 16 років), Іспанія, Нідерланди, (від 14 років). Великобританія робить виняток для неповнолітніх тільки у випадку татуювання з медичних причин. В деяких держа- вах взагалі відсутне регулювання, в наслідок чого фбахівиі сперечаються про тлумачення питання віку за аналогією з іншими нормами, зокрема Німеччина, Естонія, Бельгія.

Акцентовано на важливості знайти розумну відповідність між правом на модифбікачію тіла та зовнішнім виглядом особи у суспільстві, особливо в тому разі, якщо вказане стосується певних вимог у сфері прачі. Законодавство ичвілізованих держав визначає прийнятність наявності стандартів зовнішнъого вигляду та одягу, які обрані на підприємстві, установі організачій. Отож, роботодавець має легальне право створювати корпоративні норми, які включають в тому числі зовнішній вигляд. Представники 3 татуюванням чи пірсингом підлягають стигматизацї за фактом зовнішнъого вигляду, особливо яскраво изе проявляється під час прийому на роботу, тому вони змушені шукати роботу більи інклюзивних робочих місиях.

Право на модибікацію тіла може визначатися соматичним право людини в тому разі, якщо воно не порушує законні інтереси інших осіб. В юридичному правотворчому порядку вказане право зазвичай чітко визначається, проте діє принцип «особі дозволено робити все, що прямо не заборонено законом». Судова практика доводить, що суди не визначають дискримінаційними вимоги роботодавия щодо зовнішнъого вигляду чи вимог щодо одягу своїх працівників.

Ключові слова: соматичні права, тіло людини, модифікачія, татуювання. 


\section{Постановка проблеми}

Модифікація тіла сьогодні відбувається по всьому світу в різних формах і з багатьох причин. Приклади модифікацій тіла 3 усього світу включають пірсинг носа, пов'язаний 3 індуїзмом, подовження шиї в Таїланді та Африці, татуювання хною в Південно-Східній Азії та на Близькому Сході, видалення зубів на Балі, пірсинг губ та розтягнення мочки вух в Африці та обрізання жінок та чоловіків у багатьох регіонах світу.

Два видатні історичні приклади модифікації тіла - перев’язування ніг та корсети. Протягом сотень років в Китаї звичайно виконували цю традицію на дівчатках, починаючи від 3 до 7 років і протягом всього життя. Всі пальці ніг, окрім великого, були зламані і складені навпіл. Пов'язки змінювали часто, підтримуючи постійний тиск. До кінця процесу ноги жінки зазвичай були довжиною лише кілька сантиметрів. Хоча перев'язування ніг по суті калічить жінок, які пройшли процес, батьки продовжували практику, щоб покращити шанси дочки на одруження.

В багатьох культурах здійснювалися обмежувальні та виснажливі модифікації жіночих. У західних країнах у вікторіанську епоху жінки повинні були носити жорсткі корсети, намагаючись отримати ідеальну фігуру 3 широкими стегнами та крихітними таліями, зав'язаними на 12 дюймів. Фактично таке корсетування було формою постійної модифікації тіла [1].

Однак питання модифікації тіла є актуальним і нині. Вказане є одним 3 проявів соматичних прав, тобто права людини розпоряджатися своїм тілом. Питання прав людини нового покоління розглядали науковці як з погляду теорії, так і філософії права, зокрема С. Головатий, I. Жаровська, Ю.Бисага, П.Рабінович, С.Сливка, С.Стеценко, О. Скакун, В. Ковальчук та багато інших. Проте комплексного правового аналізу таких прав людини на модифікацію свого тіла через призму соматичної групи прав ще не було предметом розгляду.

\section{Постановка завдання}

Метою цієї статті $\epsilon$ аналіз такого виду соматичних прав людини як право на модифікацію свого тіла.

\section{Виклад основних положень}

Нині практика $є$ іншою, як то використання косметичної хірургія, пірсинг тіла, татуювання та інші. Сьогодні тисячі людей змінюють свої тіла різними химерними та незвичайними способами. Аюди, яких називають «художниками 3 модифікації тіла», проводять нетрадиційні хірургічні процедури, що варіюються від простих, таких як імплантація металевих болтів на шию людини, до самих крайніх, таких як створення хребтів під шкірою людини, для того щоб зробити їі схожим на людську ящірку. Популярними є калібрування вушних раковин та розтягування їх до гіганських розмірів.

Тенденція модифікації тіла розширюється новими та все більш химерними методами лікування. У Японії популярно серед молоді вводити велику кількість фізіологічного розчину в обличчя, потім притискаючи великий палець до середини, щоб створити відступ. Це залишає тимчасовий вигляд, що нагадує пончик, який отримав назву «голова бублика».

Науковці сучасний процес розширення способів модифікації тіла, а основне їх активно зростаючу популярність називають процесом «демократизація» модифікації тіла [2, с.1097]. Д. Робертс це пояснює так - татуювання все більш помітно в сучасних західних країнах. Колись поширене серед групи матросів, байкерів та ув'язнених, татуювання, ймовірно, стали широко прийнятною споживчою практикою, при цьому стереотипи, пов'язані 3 модифікацією тіла, стираються, і зрушення, що відбуваються в соціальному позиціонуванні цих практик.

Канадські вчені доводять, що суспільний смак змінюється, тому татуювання та інші модифікації тіла сприймалися як законні форми вираження, з вираженою особистістю через татуювання [3, с. 221].

Проте не тільки популярність через модну тенденцію $є$ прикладом активної 


\section{Теорія, історія держави і права, конституційне право}

модифікації, але й зміна психологічного сприйняття себе як особистості, бажання виокремити свою внутрішню сутність через зовнішній вигляд. Так, дослідженні студентів північноамериканських коледжів, проведених групою експертів під керівництвом $\lambda$. Діксона виявив, що татуювання можуть грати важливу функцію формування сенсу у формуванні ідентичності дорослої людини. Основними причинами, які формували рішення учасників дослідження мати татуювання, були такі як фактор пам'яті про життєві зміни, естетичну привабливість, наголос на груповій приналежності чи інших стосунках, або як згадка про близьких людей [4]. Вагітність набагато сильніше пов'язана 3 наявністю татуювань у жінок, ніж у чоловіків [5, с. 416].

Інші вчені дослідили, що жінки частіше, ніж чоловіки, мають пірсинг тіла, але татуювання частіше зустрічаються серед. Хоча татуювання були поширеними серед чоловіків і жінок у віці від 20 до 39 років, все найвищі показники татуювання були виявлені серед жінок 20-х років. Отримані дані свідчать про те, що гендерна модель татуювання може змінюватися, особливо серед молодих людей.

Правове регулювання модифікації тіла не відмічається чіткістю. Европейські країни зводять об'єм регулювання до встановлення віку за яким особа може здійснювати модифікаційні дії та ліцензування фахівців.

Датський закон про татуювання вказує, що наступає відповідальність для осіб, які проводять татуювання для осіб до 18 років, а також на голові, шиї та руках. Також вказано, що відповідальність не поширюється, якщо такі дії здійснюються за кордоном [6].

Закон Мальти «Про контроль татуювання» визначає два склади злочину «5. (1) правопорушенням будь-якої особи, якій не виповнилося вісімнадцяти років, просити, дозволяти, зазнавати або допускати татуювання будь-якої частини тіла. (2) будь-яким іншим особам здійснювати татуювання будь-якої частини свого тіла, за винятком випадків, коли татуювання виконується особою, яка володіє дійсною ліцензією» [7]. Санкція передбачає штраф, або позбавлення волі до 6 місяців. До речі, строк ліцензії на заняття тату діяльністю видається тільки на один рік.

Про потребу регулювання послуг татуювання вказують і відчизняні фахівці в цивільному праві. Слід погодитися 3 позицією А.О. Мілевської про те, що «не кожен виконавець може надавати послуги з татуювання, а тільки той, що володіє необхідними знаннями, вміннями чи кваліфікацією. Проте, аналізуючи дані послуги та практику їх надання в Україні, важко встановити якими ж знаннями чи кваліфікацією має володіти дана особа. Класифікатор професій України не містить згадок про таких фахівців, не знайдено і вимог до такої посади, що свідчить про те, що держава, оминаючи в правовому регулюванні таку діяльність, не встановлює мінімальні компетентності до виконавців послуги, що є абсолютно неправильним. Згадаємо хоча 6 про те, що дана послуга має безпосередній вплив на шкіру людини, і його безпечність може бути досягнута лише тоді, коли особа володіє необхідними знаннями 3 анатомії, правил здійснення місцевої анестезії, розрізняє асептики та антисептики, вміє запобігати розвитку алергічних реакцій і т.д. Тобто, дана особа має мати медичну кваліфікацію, а не лише пройти курси майстрів татуажу» [8, с.327].

Щодо віку позиції країн також розбіжні. Більшість держав дозволяють татуювання після повноліття, однак деякі держави передбачають право отримання дозволу у батьків у більш ранньому віці Австралія, Австрія Хорватія, Словаччина, Україна (від 16 років), Іспанія, Нідерланди, (від 14 років). Великобританія робить виняток для неповнолітніх тільки у випадку татуювання 3 медичних причин. До речі, в деяких державах взагалі відсутне регулювання, в наслідок чого фахівці сперечаються про тлумачення питання віку за аналогією з іншими нормами, зокрема Німеччина, Естонія, Бельгія.

На рівні законодавчої ініціативи нині розглядається питання про заборону татуювання в Росії. Мотивація наступна тату слід розглядати як крайню ступінь язичництва. Татуювання небезпечні для здоров'я i можуть привести до виникнення смер- 
тельно небезпечних захворювань. Також тату про "духовному інтелектуальну кризу» і надлишку статевих гормонів у людини, їх носять [9].

Акцентуємо на важливості знайти розумну відповідність між правом на модифікацію тіла та зовнішнім виглядом особи у суспільстві, особливо в тому разі, якщо вказане стосується певних вимог у сфері праці. Законодавство цивілізованих держав визначає прийнятність наявності стандартів зовнішнього вигляду та одягу, які обрані на підприємстві, установі організації. Така уніфікація має ряд переваг, що включають вирівнювання працівників під брендом організації, професіоналізація роботи, відповідність нормам охорони праці та безпеки та створення почуття організаційної ідентичності. Уніформи створені для того, щоб допомогти членам громадськості швидко визначити персонал та звернутися за допомогою до правильного члена персоналу. Отож, роботодавець має легальне право створювати корпоративні норми, які включають в тому числі зовнішній вигляд.

Представники 3 татуюванням чи пірсингом підлягають стигматизації за фактом зовнішнього вигляду, особливо яскраво це проявляеться під час прийому на роботу, тому вони змушені шукати роботу більш інклюзивних робочих місцях. За даними XpertHR (2015), багато роботодавців створюють вимоги до одягу працівника та 3овнішнього вигляду на робочому місці. За результатами опитування, 578 роботодавців у Великобританії повідомлялося, що: майже три чверті вибірки застосовували політику дрес-коду; найбільша користь від запровадження норм одягу була сприйнята як «встановлення стандартів» уставлення до культури робочого місця; татуювання та пірсинг були дозволені лише у $41 \%$ опитаних організацій [10, с.67].

Наприклад, у Starbucks, співробітники ініціювали онлайн-петицію, спрямовану на зміну політики татуювання. В наслідок иї працівникам було дозволено демонструвати татуювання за умови, що воно $\epsilon$ «зі смаком» і не видно на обличчі або горлі [11].

В літературі описаний наступний казус. Жінку журналістку з татуюванням попро- сили прикрити його на час телепередачі, вона не доклала жодних зусиль, щоб зробити це і тому була звільнена. Суд визнав, що дії роботодавця не вбачали дискримінації [12].

Розширюються стандарти визначення ідентичності навіть для представників правоохоронних органів. Судовий позов розглядався у 2012 р. у федеральної землі Північний Рейн-Вестфалія Німеччини, оскільки чоловіка не допустили до конкурсу для навчання на поліцейського. Підставою було наявність татуювання на обох руках у вигляді черепа, жіноче лице із зав'язаним ротом і бійцівський собака, оскільки такий вигляд несумісний з принципами нейтралітету службовця поліції. Суд запропонував компромісний варіант: на службі чоловік повинен завжди з'являтися в одязі 3 довгим рукавом [13].

Репрезентативним є прецедент СIIA, що стосується дискримінації на підставі зовнішнього вигляду «Cloutier v. Costco Wholesale Corp», де заборона працівнику носити ювелірні вироби також було висунуто як вимога релігійної дискримінації. Кімберлі Клутьє стверджувала, що іï роботодавець, нерозумно ставився до прикрас для обличчя, що було основою її релігійної практики як члена Церкви модифікації тіла. Перед першим робочим днем Cloutier отримала копію трудової угоди, яка містила дрес-код працівника. Коли ії найняли, у Клутьє було кілька сережок та чотири татуювання, але жодного пірсингу на обличчі. 3 часом Клутье займалася різними формами модифікації тіла, включаючи пірсинг обличчя та різання шкіри, які, як вона визнала, не були мотивовані релігійною вірою. Підприємство переглянуло свій дрес-код, щоб заборонити будь-які прикраси для обличчя, за винятком сережок, але позивачка не врахував нову політику, тому була звільнена. Суд обгрунтував, що Costco мало законний інтерес представляти перед клієнтам досить професійний вигляд. Будучи касиром, позивачка регулярно спілкувалася 3 клієнтами, і їі пірсинг обличчя погіршував професійний образ, який був на розсуд Костко. Суд відкинув тут релігійний чинник як дискримінаційний [14]. 


\section{Теорія, історія держави і права, конституційне право}

\section{Висновок}

Право на модифікацію тіла може визначатися соматичним право людини в тому разі, якщо воно не порушує законні інтереси інших осіб, особливо на сучасному етапі демократичних перетворень в Україні, який «характеризується загостренням політичних і соціальних суперечностей»[15, с. 242]. В юридичному правотворчому порядку вказане право зазвичай чітко визначається, проте діє принцип «особі дозволено робити все, що прямо не заборонено законом». Судова практика доводить, що суди не визначають дискримінаційними вимоги роботодавця щодо зовнішнього вигляду чи вимог щодо одягу своїх працівників.

\section{Лiтература \\ 1. Bradley University. The Body} Project URL: https://www.bradley.edu/sites/ bodyproject/disability/modification/

2. Roberts D. Modified People: Indicators of a Body Modification Subculture in a Postsubculture. World Sociology. 2015. №49(6).P. $1096-1112$.

3. Atkinson M. Pretty in Ink: Conformity, Resistance and Negotiation in Women's Tattooing. Sex Roles. 2002. № 47(5-6). P. 219235.

4. Dickson L., Dukes R., Smith H., Strapko N. To Ink or Not to Ink: The Meaning of Tattoos among College Students. College Student Journal. 2015. V.49(1). P. 106-120.

5. Tranter B. Grant R. A class act? Social background and body modifications in Australia. Journal of Sociology. 2018. 54:3. P. $412-428$

6. Lov om Tatovering. Nr.194. URL: http://www.tattoo.dk/old-website/engelske/ law_on_tattooing.html

$\overline{7}$. Control of tattooing Act. (28th December 1976) http://www. justiceservices.gov.mt/DownloadDocument. aspx?app $=$ lom\&itemid $=8760 \& \mathrm{l}=1$

8. Мілевська А. О., Бережнюк Т. О. Цивільно-правова характеристика договору про надання послуг з татуювання. Biсник Аьвівського торговельно-економічного університету. Юридичні науки. 2018. Вип. 7. C. $325-332$.
9. Депутаты Госдумы хотят законодательно запретить татуировки в России: это язычество и вред здоровью URL: https:// www.newsru.com/russia/24feb2020/tatu.html

10. Timming A. R. Visible tattoos in the service sector: a new challenge to recruitment and selection. Work, Employment \& Society. 2015. V. 29(1).P. 60-78.

11. Bradford H. Starbucks to finally let employees show their tattoos. The Huffington Post online. 2014 URL: http://www. huffingtonpost.com/2014/10/16/starbuckstattoos-policywork_n_5999746.html

12. Guardian. Are Tattoos Unprofessional? 2014 URL: http://www.theguardian.com/ commentisfree/poll/2014/jul/10/tattoosunprofessionalwoman-sacked

13. Тату формі не перешкода. Закон $i$ Бізнес. №49 (1088) URL: https://zib.com.ua/ ua/print/13097-u_nimechchini_sud_dozvoliv_ brati_na_robotu_v_policiyu_z_tatu.html

14. Perkins E. J. Regulating Appearance In The Workplace: An Employer's Guide To Avoid Employment Discrimination Lawsuits. The National Law Review. March 17, 2020.

15. Жаровська I. М. Генезис ідеї відкритості влади Форум права. 2009. № 3. С. $242-$ 246.

\section{SOMATIC HUMAN RIGHT TO MODIFY HIS/HER BODY}

Body modification is happening all over the world today in many forms and for many reasons. Historically, many cultures have undergone restrictive and debilitating modifications of female bodies. Now practice is different, such as the use of cosmetic surgery, body piercing, tattoos and others. The trend of body modification is expanding with new and increasingly bizarre methods.

Scientists call the modern process of expanding ways of body modification, and mainly the actively growing popularity, the process of "democratization" of body modification. It's also proven that the public taste is changing, so tattoos and other body modifications are seen as legitimate forms of expression, with an expression of personality through tattoos.

Legal regulation of body modification is not clear. European countries reduce the 
amount of regulation to the age at which a person can perform modification and licensing of specialists. The latter activity is not governed by national rules of civil law.

It is analyzed that countries' positions on age are also different. Most states allow tattoos after the age of majority, but some states provide for the right to obtain permission from parents at an earlier age: Australia, Austria, Croatia, Slovakia, Ukraine (16 years old), Spain, and Netherlands (14 years old). The UK only makes an exception for minors if they are tattooed for medical reasons. In some countries, there is no regulation whatsoever, which is why experts argue about interpreting age by analogy with other norms, such as Germany, Estonia, and Belgium.

Emphasis is placed on the importance of finding a reasonable match between the right to body modification and the appearance of the individual in society, especially if the above applies to certain requirements in the field of work. Legislation of the civilized States determines the admissibility of the presence of standards of appearance and clothing, which are selected at the enterprise, institution, organization. Therefore, the employer has a legal right to create corporate norms that include appearance. Representatives with tattoos or piercings are stigmatized by appearance, especially when they are hired, so they are forced to look for jobs in more inclusive workplaces.

The right to body modification may be determined by a somatic human right insofar as it does not violate the legitimate interests of others. In law-making, this right is usually clearly defined, but there is a principle "a person is allowed to do anything that is not expressly prohibited by law." The case law has shown that courts do not find discriminatory employer requirements for appearance or their employees' clothing requirements.

Keywords: somatic rights, human body, modification, tattoos. 